\title{
Hans Brun: a Swiss pioneer in the surgery of the spinal cord, brain and herniated lumbar disc
}

\author{
Gerhard Hildebrandt • Martin N. Stienen • \\ Werner Surbeck • Ulrich Tröhler
}

Received: 19 June 2014 / Accepted: 24 June 2014 /Published online: 30 July 2014

(C) Springer-Verlag Wien 2014

\begin{abstract}
Introduction Toward the end of the nineteenth century, it was Gowers, Horsley and Macewen who first reported successful surgical procedures for the treatment of subdural extramedullary tumors. Following this, Church and Eisendrath as well as Putnam and Warren reported unsuccessful attempts to treat subpial spinal pathologies in their patients. Only at the beginning of the twentieth century did reports of successful interventions of this type accumulate. In the analysis of these case reports, the authors noticed a certain lack of accuracy about the anatomical allocations and descriptions of intra- and extramedullary spinal lesions. From this, the question of who actually carried out the pioneering works in the early twentieth century in the field of surgery of intramedullary pathologies arose.

Methods Analysis of the relevant original publications of Hans Brun and research on the poorly documented information about his life history by personally contacting contemporary relatives.

Results The literature analysis showed that the Swiss neurologist Otto Veraguth and surgeon Hans Brun made fundamental contributions to subpial spinal cord surgery at the very beginning of the last century that remain valid today. According to our research, Hans Brun should be remembered as the third surgeon (after von Eiselsberg and Elsberg) who successfully removed an intramedullary lesion in a patient.
\end{abstract}

G. Hildebrandt $(\triangle) \cdot$ M. N. Stienen $\cdot$ W. Surbeck

Department of Neurosurgery, Kantonsspital Sankt Gallen,

Rorschacher Str. 95, 9007 St.Gallen, Switzerland

e-mail: gerhard.hildebrandt@kssg.ch

M. N. Stienen

e-mail:mnstienen@gmail.com

U. Tröhler

Institute for Social and Preventive Medicine, University of Berne,

Berne, Switzerland
Conclusion Brun should be remembered as an early and successful surgeon in this specialized field. His operative work is described in detail in this article. At the same time, his achievements in the fields of brain and disc herniation surgery are presented.

Keywords Hans Brun · Neurosurgery · Medical history · Spine surgery $\cdot$ Medullary surgery $\cdot$ Otto Veraguth $\cdot$ Spinal cord surgery

\section{Introduction}

Victor Horsley (1857-1916), William Richard Gowers (18451915) and William Macewen (1848-1924) must be credited with inaugurating the successful surgery of spinal intradural, extramedullary lesions. Horsley removed a spinal intradural meningioma on 9 June 1887 and Macewen in 1888, each with a successful postoperative course in their patients $[18,33]$. They extensively discussed the neurological differential diagnosis of their cases and provided valuable information on the surgical aspects of these pathologies [18, 33]. Already in 1890, Abbé reported on eight patients who had undergone spinal surgical measures, with partial neurological improvement [1]. Further reports of surgical therapy followed, but still with the main focus on the resection of intradural extramedullary lesions and other intradural pathologies $[9,21,25,26,29,31,34-42$, $46,48,57,58]$.

Not infrequently in these publications, the term "Rückenmarkstumor" (spinal cord tumor) was imprecisely used for extramedullary entities as well. In this pioneering time, the surgical therapy of extramedullary spinal tumors or of other intradural pathologies was provisionally associated with a high risk of death or neurological worsening. Krause reported in 1906 that five operations had been successful; six patients had died after surgical therapy for 
"Rückenmarkshautgeschwülste" (tumors of the medulla and its covering) (author's note: Krause meant purely extramedullary findings) [26].

A few years later, the first attempts were made to treat also spinal intramedullary lesions surgically [11, 30]. However, these interventions initially ended unsuccessfully for both the patient and surgeon. In 1909, Krause announced with optimism that he would also be able to remove intramedullary tumors, after having successfully resected a medullary cyst and a malacia of the spinal cord, respectively, in two patients [28]. Von Eiselsberg can be counted among the European pioneers who first successfully resected intramedullary lesions, in the sense of accomplishing postoperative improvement of neurological symptoms. He took out a $4 \mathrm{~cm}$ subpial tumor ("neurofibrosarcoma") of the thoracic spinal cord already on 13 November 1907 [58].

The first report of a resection of a cervical glioma with postoperative improvement in the neurological symptoms came from Elsberg and Beer $[15,16]$. The two-stage surgery was performed on 13 and 20 January 1910 by Elsberg. After laminectomy of the fourth cervical vertebra to the first thoracic vertebra (C4-Th1), a tumorous lesion was resected that was later diagnosed as a "gliosarcoma" [16].

Only 26 days after the Elsberg/Beer operation, the Swiss surgeon Hans Brun (1874-1946; Fig. 1) performed surgery on a 32-year-old railway employee [55]. In the private hospital "Im Bergli," Lucerne, Switzerland (Fig. 2), he chose a C3-4 laminectomy to remove a solitary tuberculoma of the subpial cervical medulla. Postoperatively, the patient soon recovered

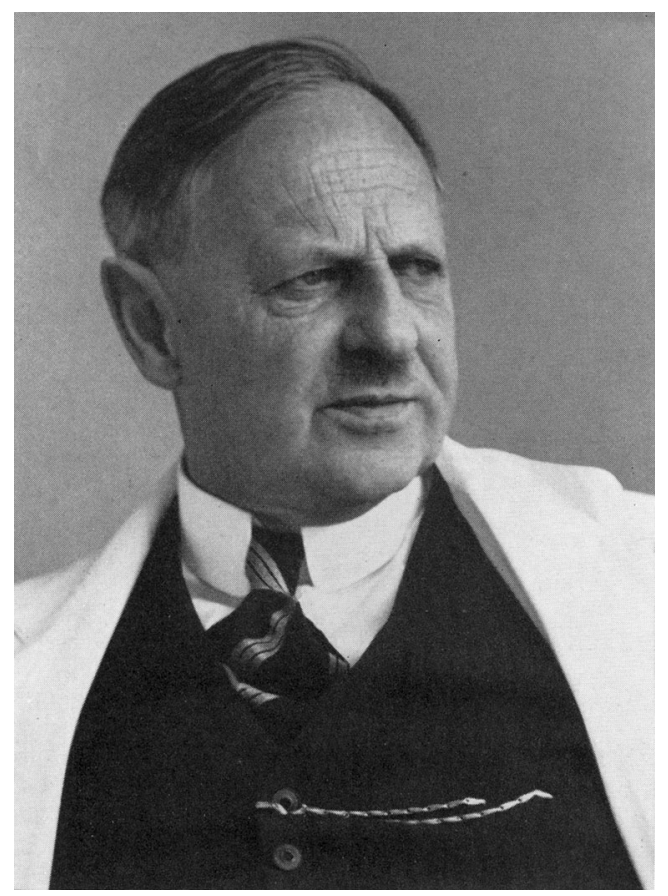

Fig. 1 Hans Brun (1874 - 1946) from [53] (1944)

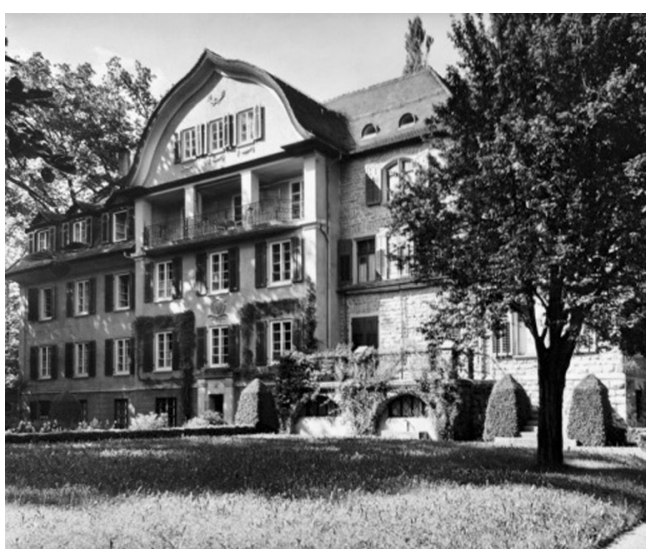

Fig. 2 Photograph from 1920: Brun's private hospital in Lucerne after the expansion (courtesy of the family; permission was obtained from the family to reprint this photograph)

and experienced a marked improvement in his preoperative neurological deficits.

Elsberg and Beer commented on a further operation (2 February 1910) with C4-Th1 laminectomy [16]. After removal of a cystic glioma, the patient died. Röpke operated on a patient with von Recklinghausen disease with multiple intradural neurofibromas in the summer of 1910 [42]. He also removed an intramedullary tumor during this procedure and reported the patient's postoperative neurological improvement [42]. Rothmann cited a first unpublished oral communication from von Eiselberg, according to which the latter had removed an intramedullary cyst from the cervical spinal cord on 25 November 1910 [44]. This patient was also reported to have experienced postoperative neurological improvement (author's note: this communication was later confirmed by von Eiselsberg and Ranzi [58]). Schultze mentioned the successful resection of a cervical intramedullary cavernoma on 1 January 1912 [47].

In the period from 21 September 1910 to 16 December 1913, Otto Veraguth (1870-1944) and Hans Brun described three further interventions in which surgical treatment of spinal cord lesions had been carried out. This work will first report the outcomes of three patients, the total of four surgical procedures carried out by Brun and his extremely innovative surgical approaches in detail and will discuss them in the context of the experience with spinal cord surgery at that time. In addition, we will report Hans Brun's achievements in the surgical therapy of herniated lumbar discs, which he first successfully performed in October 1929 [54]. His early publication in this field has only recently been appreciated [50]. His further contributions in the field of brain surgery are likewise acknowledged in retrospect $[2-5,7,8]$, although they are not the primary focus of this report. Still, these aspects of the sovereignity of Brun's contributions to neurosurgery have not been considered so far in 
the standard works on the history of neurosurgery or the medical history literature $[10,19]$.

\section{Methods}

This historical work is based on analysis of the relevant original publications of Hans Brun, which are all cited in this work (see references). In addition, one of the authors (U.T.) examined the life data of Hans Brun through personal research and by contacting contemporary relatives. This information about his life has hitherto only been poorly documented.

\section{Results}

Biography of Hans Brun (1874-1946) [49]

Hans Brun (Fig. 1) was born on 17 June 1874 in Lucerne, Switzerland. His father and his scholastic education inspired him to study the natural sciences. In Zurich, he began to study medicine in 1892 . He financed his studies by selling photographs of the Swiss alpine countryside. He was an enthusiastic mountaineer and reached the summit of all Swiss mountains of $>4,000 \mathrm{~m}$ altitude. From 1898 to 1902 he was first the assistant and later senior physician at the University Hospital of Zurich under the surgeon Rudolf Ulrich Krönlein [22]. His first scientific contribution (dissertation) dealt with skull fractures in 470 patients and comprised 350 pages $[4,8]$. To deepen his education, he undertook an educational journey to Germany, Italy, France, North Africa, Spain and Portugal in 1903. Supported by financial resources from his family, Brun constructed a private clinic on a beautiful hill ("Im Bergli") in Lucerne (Fig. 2). There, from 1903 onwards (at the age of 29 years), he autonomously operated on an average of 350 patients per year in the areas of abdominal surgery, traumatology, orthopedics and neurosurgery $[2,3,5,7,8]$. He was an opponent of subspecialization. In the period from 1914 to 1942 he lectured at the University of Zurich on the traumatology of the musculoskeletal system. He supervised $18 \mathrm{PhD}$ students. In 1914, the University of Zurich awarded him the venia legendi in recognition of his achievements [52]. In 1935 he was awarded a titular professorship. Brun retired in 1942.

According to his own statements, Brun had performed a total of 458 "Schädelgehirnoperationen" (operations on the skull and brain) by 1926, including 28 interventions for brain tumors $[2,3,5,7,8]$. Brun was also one of the first surgeons internationally to successfully operate on a herniated lumbar disc [50]. Brun was one of the founders of the Swiss Society of Surgery in 1913. His partner and friend for many years was the Zurich-based neurologist Otto Veraguth (1870-1944) [51]. Hans Brun died on 23 June 1946.

\section{Biography of Otto Veraguth (1870-1944) [51]}

Otto Veraguth was born on 3 May 1870 in Chur, Switzerland. He received his medical degree in 1894 and finished his dissertation in 1895 . Following initial clinical activity in psychiatric hospitals, he then went to Paris and met Pierre Marie, Jean-Marie Charcot, Edouard Brissaud, Joseph Babinski and Joseph-Jules Déjerine. For half a year he visited Victor Horsley in London, where he discovered his enthusiasm for the burgeoning specialty of neurosurgery. He then became an assistant at the neurological clinic in Zurich under Constantin von Monakow, who also engaged him for his Institute for Brain Anatomy. Veraguth opened a neurological private practice in Zurich in 1897, but continued his work at the Institute for Brain Anatomy. In 1900 he received his habilitation. With other coworkers he elaborated the statutes of the Swiss Neurological Society, founded by Constantin von Monakow and Paul Dubois in 1908. In 1918 Veraguth obtained the chair of physical therapy and was appointed director of the Institute and Polyclinic for Physical Healing Methods. From 1930 to 1932 he was Dean of the Medical Faculty of the University of Zurich. During his career, Veraguth performed 19 operations on the spinal cord himself:

"Neurochirurgie, und nicht am wenigsten diejenige des Rückenmarks, ist ein herrlicher, ein beglückender Fortschritt."

(Neurosurgery, and not least that of the spinal cord, is a delightful, a blissful progress.").

Besides Brun, he assisted other surgeons such as Eugen Tschudi, Oscar Wyss and Paul Clairmont. He visited Victor Horsley and Charles Elsberg in New York. In his position as a responsible diagnostician, Veraguth recommended surgery for more than 50 patients.

Intramedullary surgeries performed by Brun

\section{Case 1 [55]}

A 32-year-old railway employee complained of neck pain and sensory disturbances of the left arm. He developed a numb feeling in the umbilical region. When sitting, he felt pain in his left leg. He presented with a pain-related malposition of the head to the front. The neurological examination revealed a loss of sense of position and tactile sensation in his left hand, hypesthesia of the left shoulder and a left arm paresis with increased tendon reflexes. Fibrillations were found in the area 
of the triceps and deltoid muscles. Concerning the lower limbs, an increase of spastic muscle tone was found in the left leg with increased tendon reflexes in both legs. The Babinski phenomenon was positive on the left side. The disturbances, especially the left arm and leg paresis, were progressive. The patient developed the clinical signs of Brown-Séquard syndrome with additional left-sided phrenic nerve palsy. Lumbar puncture showed water-clear cerebrospinal fluid (CSF) without abnormalities. The radiograph of the cervical spine was regular. Tubercle bacilli were detected in the patient's sputum.

In view of the progressive symptoms, explorative surgery was performed on 15 February 1910 in the private clinic "Im Bergli," Lucerne (Fig. 2). With the patient under ether anesthesia and in the right lateral position, Brun performed laminectomy of the third and fourth cervical vertebrae. He suspected an extramedullary tumor localization because of the BrownSéquard syndrome, but an intramedullary process was not precluded. After a median durotomy, he encountered a swollen spinal cord. Palpation in this region of the spinal cord revealed increased resistance. There, a median dorsal incision was made, and a well-defined, subpially situated tumor measuring $17 \mathrm{~mm}$ in the longest diameter was removed, which later proved to be a tuberculoma. During the process of wound closure, the dura was sutured watertight. Postoperatively, the patient was discharged 8 weeks after surgery. He experienced a significant regression of the preoperative neurological deficits within 3 months. The patient reported performing a $7 \mathrm{~km}$ march on 26 June 1910 4 months after the operation. With his left arm, he was able to raise a chair up to the horizontal position. He survived 3 years and was able to return to work until dying of lung tuberculosis.

\section{Case 2 [6]}

Veraguth prompted the referral of a 28 -year-old man to the private clinic "Im Bergli," Lucerne, on 5 September 1910. The patient presented with a progressive atrophic paresis of the left leg. In the right half of the body, a disruption of temperature and pain perception to the level of the eighth thoracic vertebra was found. The tendon reflexes were increased in both legs. The paraparesis of the legs was progressive. This was assumed to result from an extramedullary sub- or epidural tumor with left-sided compression of the spinal cord. Twice, no CSF could be obtained during repeated lumbar puncture.

Brun performed the operation on 21 September 1910 with the patient under ether anesthesia and in the lateral position. In $105 \mathrm{~min}$, laminectomy between the sixth and nineth thoracic vertebrae was performed, followed by a median durotomy (Fig. 3). The spinal cord was opened over $4 \mathrm{~cm}$ in the posterior midline in the area of increased resistance. A well-marginated glioma (according to surgeon's opinion) was resected. Again, watertight dural closure was performed. Postoperatively, the sensory disturbances increased, while the motor function corresponded to the preoperative situation. Until the 7 th

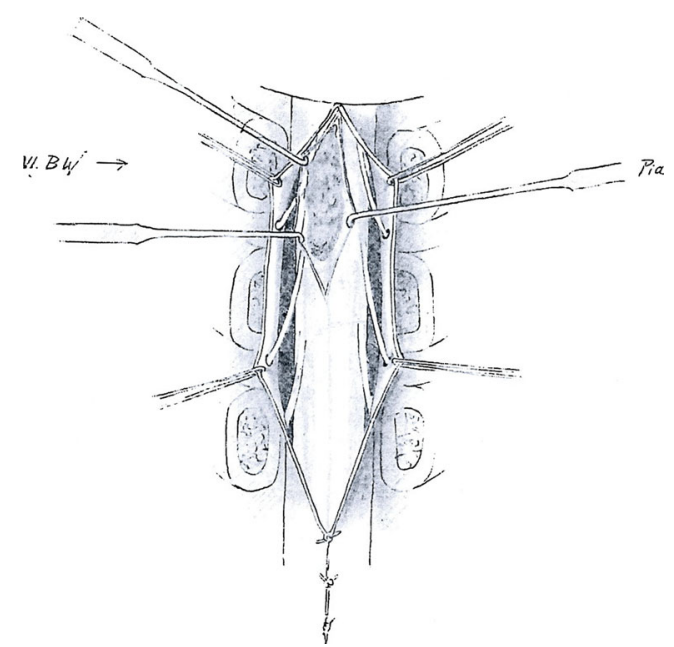

Fig. 3 Sketch of the intraoperative macroscopic findings in case 2 (see text) with subpial preparation of the intramedullary lesion (histologically: glioma). VI. BW=Sixth thoracic vertebral body. The figure was remade by the authors; it is based on the original publication [6]

postoperative day, a CSF-fistula was documented, which regressed spontaneously. The patient died on 4 October 1910 of purulent meningitis.

\section{Case 3 [56]}

A 33-year-old patient had fallen ill because of a tuberculous pleuritis in the year prior to his admission and was treated in a sanatorium in Davos, Switzerland. He reported marked pain in the left arm, and a hyperpathia was noted in the painful area. The patient showed signs of a central paresis of the left arm and leg with increased muscle tone. In addition to a patellar and ankle clonus, the Babinski phenomenon was demonstrated on both feet. In the right half of the body between the height of the shoulder blade and knee, a "thermhypaesthesia" (diminished ability to sense temperature) and hypalgesia were found. The neurological symptoms escalated, and the initially diagnosed Brown-Séquard syndrome was superseded by prominent bilateral neurological deficits.

Brun perfomed the operation on 13 November 1913 with the patient under ether anesthesia and in the prone position. After laminectomy between the fourth and seventh cervical vertebrae, a median durotomy was performed. In the region of the spinal cord with increased resistance, a median incision was made, and at $2 \mathrm{~mm}$ depth, a 14- $\mathrm{mm}$ tuberculoma was completely removed at the level of the sixth cervical vertebra. The dura was sutured in a watertight manner; a drain was not placed. A CSF fistula did not occur.

Within 14 days after the procedure, a significant improvement of the sensory and motor disturbances in the right half of the body was noted; however, these were accompanied by newly developed pain in the right arm. Finally, a new hypesthesia and later anesthesia developed on the patient's left side between the second rib and the foot. 
This development led to a revision surgery on 16 December 1913. At the level of the fourth cervical vertebra, Brun resected a second tuberculoma measuring $10 \mathrm{~mm}$ by paramedian incision of the spinal cord. Postoperatively, a flaccid paralysis of the right leg emerged in the operated patient. Within days, a progressive sensory-motor paraplegia with bladder paralysis was noted. The patient died on 5 Janaury 1914. Autopsy of the deceased revealed multiple tuberculomas in the region of the pons and the spinal cord.

Fundamental considerations and concepts for spinal surgery

After these experiences, Veraguth and Brun developed and formulated fundamental considerations and concepts for spinal surgery $[6,56]$. Brun's surgical techniques were characterized by the following considerations and recommendations, according to the following original formulations:

"Der definitive Erfolg solcher heute noch höchst bedenklicher Eingriffe hängt aber mehr als bei manch anderer Operation von unserem technischen Können und von subtilsten Einzelheiten ab, und es lohnt sich deswegen wohl der Mühe, im folgenden nun noch näher auf die in diesem Falle gemachten chirurgischen Erfahrungen einzutreten" [6].

(The final success of such interventions, which are still highly questionable today, depends even more than many other operations on our technical skills and on subtle details. It is thus worth the effort to go into the details of the surgical experiences gained during these cases in the following.)

Based on his experience, Brun formulated surgical maxims for spinal cord surgery, which are summarized in Table 1 [6].

\section{Discussion}

One of the first surgeons to point out the surgical options for extradural spinal pathologies was the Swiss surgeon and Nobel laureate Emil Theodor Kocher [23]. It was then Gowers and Horsley [18] and Macewen [33] who first reported successful resections of spinal intradural extramedullary lesions at the end of the nineteenth century. The initial efforts to treat intramedullary lesions surgically had been unsuccessful [1, $11,30]$. In his 478-page contribution on "Die Klinik der Rückenmarks-Krankheiten" (The Clinic of Spinal Cord Diseases), released in 1874, Leyden could only report on clinical and patho-anatomical experiences with tumors of the spinal cord in seven pages (author's note: in this contribution, he placed special emphasis on intramedullary tuberculomas) [32].
Table 1 Brun's surgical maxims after performing four surgical procedures for intramedullary spinal cord processes

(1) General considerations/narcosis

Preoperative administration of concentrated opium

Ether anesthesia if the patient is already affected by a high level of pain before the operation

Otherwise, use local anesthesia (LA). Here, Brun points out that the use of LA:

- Allows recognition of the patients' reactions, which otherwise remain unobserved under ether anesthesia

o Produces a hemostatic effect

Brun ultimately prefers ether anesthesia in combination with LA to avoid vascular responses while manipulating on the spinal cord (for example, a spinal "shock"). He rejects the use of subdural anesthesia

In unproblematic cases, Brun generally recommends a one-stage operation Brun denies the pain sensitivity of the dura

Brun considers the main causes of fatal clinical courses in patients undergoing spinal surgery:

$\circ$ Long duration of the surgery

$\circ$ Laminectomies on multiple segments

$\circ$ Extensive durotomies

○ Postoperative shock

- General postoperative adynamia of patients ("prostration syndrome" according to the former nomenclature) because of excessive CSF loss, which can lead to persistent vomiting

$\circ$ Postoperative gastrointestinal paralysis

Brun regards the age and general medical constitution of the patient as less important factors for survival

(2) Approach to the spinal canal

Brun regards fast preparation including laminectomy with robust/sharp instruments as important

Brun mentions the laminotomy technique. He quotes Hofmann [24], who described a simple technique for temporary laminectomy, and the contribution of Röpke [43]

The application of "nassheisser" (wet, hot) compresses to establish hemostasis

Use of appropriate retractors, also to establish hemostasis

Also in case of laminectomies on multiple segments, Brun is not concerned with postoperative instability

Brun generally recommends performing laminectomies on four segments, because additional post hoc laminectomies are time consuming (because of the additional hemostasis)

Brun advises the use of a "modifizierte Dahlgrensche Instrument," which squeezes the bone and thus supports hemostasis

Hemostasis at the edges of the bone should be carried out by compression with muscle pieces. Other materials that may be useful are iodoform gauze and tampons that contain a platelet-derived hemostatic substance

\section{(3) Dural opening}

After a short pause (after the laminectomies), Brun recommends a "... subtiles Vorgehen mit ausgeruhter Hand und feinen Instrumenten, langsam und streng systematisch" (...a subtle approach with wellrested hands and fine instruments, slowly and strictly systematic)

The dura should be incised longitudinally; a wing-like door opening does not allow further extension of the incision

Brun stresses that the inflow of blood in the subdural space must be avoided 
Table 1 (continued)

Brun advises using the Trendelenburg position (the patient's torso should be kept low) to minimize the CSF outflow

Brun warns against the abrupt relief of previously dammed CSF by the durotomy; this could lead to intramedullary hemorrhage

Brun points out that the dura can be lightly compressed cranially to the durotomy or can be restricted by suture wrapping to control the CSF outflow

"...das Austupfen intradural muss ein zartes Vorgehen bedeuten und mit leichter Hand geschehen" (...intradural dabbing is a delicate procedure and must be done with a light hand)

(4) Approach to intramedullary lesions

Brun recommends probe palpation through the meshes of the denticulate ligament and/or the sectioning of these ligaments in order to inspect laterally and anteriorly to the spinal cord. Brun considers the subtle exploration of the caudal and cranial subdural space essential

In case of unrewarding inspection, a positive palpation finding (analogous to the palpatory exploration in brain tumor surgery) allows for the exploratory opening of the spinal cord in the posterior fissure or in the area of the posterior columns

Brun stresses the importance of palpation of the spinal cord, as intramedullary pathologies might otherwise be overlooked

For the enucleation of tuberculomas, a semi-sharp curette should be used

A subtle treatment of the pia mater and the spinal cord reduces postoperative arachnoid changes/adherences

(5) Dural and wound closure

A watertight suture of the dura with individual button sutures or preferably continuous suturing using the finest silk is essential. If not possible, the seam of the soft tissue should be created in a watertight manner

Brun uses a periosteal soft tissue flap to seal the dural suture and to support the regeneration of the dura

The prevention of postoperative CSF fistulae helps to prevent secondary infections

Brun advises against the use of a sub- or epidural drainage in order to prevent possible hematomas of the wound cavity. $\mathrm{He}$ stresses that drainages with contact to the dural seal must be avoided

Postoperatively the patient should be placed in the prone position Brun recommends outward CSF drainage in case of postoperative meningitis if the CSF outflow through the skin has ceased at this time

Therapeutically, only medical therapy (including drugs) and general recommendations for the patient's behavior, therapeutic exercise, baths, electrotherapy, and treatment of decubitus and cystitis were considered possible [32]. As he put it:

\section{"Wenn die Möglichkeit einer Exstirpation von Rückenmarkstumoren durch Trepanation der Wirbelsäule ins Auge gefasst werden soll, so kann diese Indication fast nur für die Meningealtumoren, allenfalls für die peripheren Medullartumore aufgestellt werden..." [32].}

(If the possibility of extirpation of spinal cord tumors by trepanation of the spine should be considered, this indication can almost only be recommended for meningiomas and, if necessary, for peripheral medullary tumors...).
During this time period, Schlesinger advised very strongly against interventions involving the medullary substance of the spinal cord:

\section{"Absolut ausgeschlossen von einer Operation sind die im Rückenmarke central gelegenen Geschwülste." [45]. (Absolutely excluded from surgery are the tumors located centrally in the spinal cord).}

Schlesinger based his statement on extensive pathoanatomical analyses that he had conducted at the Vienna Pathological Institute [45]. In 35,000 autopsy protocols collected over an 18-year period, he found 151 of the deceased had tumors of the spinal cord or its membranes. Among these, 62 intramedullary tuberculomas [so-called "Solitärtuberkel" (solitary tuberculomas), according to the nomenclature then if they were solitary findings] and 20 gliomas (with or without accompanying syringomyelia) were detected. If both lesions occurred together, they were most frequently found in the area of the cervical spinal cord. Among others, the difficulty of the preoperative localization diagnosis, the possibility of multiple occurrence of an intramedullary pathology (especially true for tuberculosis or gummata in the context of syphilis), the controversy surrounding the biological nature of gliomas at that time as well as distinct problems in the histological classification constituted the main arguments for his reluctance to use operational measures. After Schlesinger, an operation was solely indicated in case of evidence of Brown-Séquard syndrome or the presence of radicular signs. Surgery was not to be used in case of bilateral progression of limb disorders or neurological signs. Schlesinger supported the authority of his statements with research of the medical publications of his time. In 589 analyzed publications, he found 400 patients with 400 lesions of the spinal cord or its membranes, including 125 patients with intramedullary localizations (author's note: mainly tuberculomas, the second most common: glioma) [45]. From his own series of 151 patients, Schlesinger presented the medical history, clinical progression of the disease as well as autopsy findings of 50 patients in detail. His report contained patients with intramedullary lesions, none of whom had undergone operations [45].

In this respect, it represented a paradigm shift when a few authors and/or their cooperating surgeons defied the traditional dogma and concerns as well as apparent technical limitations in the field of spinal surgery and developed authoritative principles and concepts for resecting spinal lesions for the benefit of their patients at the beginning of the twentieth century $[6,12,15-17,27,42,47,55-58]$. However, initially, the quality of the scientific evidence did not go beyond individual case reports. Even Krause, who had carried out a total of 39 spinal durotomies for intradural processes by 1911 (including 9 patients with lethal outcome), could only report on one patient with a spinal glioma (with a neurologically stable 
postoperative course) and two interventions for intramedullary tuberculomas [27]. Decades would pass before the resection of intramedullary pathologies could be referred to in higher case numbers and with better success rates $[14,59]$.

Against this background, it appeared important to the authors to point out another pioneer of spinal neurosurgery at the beginning of the twentieth century who received a great deal of attention from his former colleagues because of his outstanding surgical services, but is apparently no longer remembered today despite his fundamental contributions to the surgical therapy of lesions of the spinal cord, brain and herniated lumbar discs: the Swiss surgeon Hans Brun (1874-1946). The special value of Brun's [6] and Veraguth and Brun's reports $[55,56]$ is that the operative aspects are provided in detail by the participating surgeon himself (as a first or co-author) and are discussed directly. Moreover, Brun gave detailed information not only about the type of surgical complications, but also on the surgical technique (Table 1).

Still in 1918, von Eiselsberg and Marburg gave Veraguth and Brun the credit for having operated on a patient with an intramedullary lesion "...von vornherein operiert..." (in the first place) [57]. At the time of their first surgery on a patient with an intramedullary lesion on 15 February 1910, Veraguth and Brun were not aware of the fact that such an operation had already been carried out successfully [53, 55]. Von Eiselsberg's first surgery for an intramedullary lesion had been performed on 13 November 1907, but was not published until 1913 [44, 58]. Elsberg dared to perform his first successful surgery on a patient with a cervical intramedullary glioma in two stages on 13 and 20 January 1910. He had performed two such operations by $1911[15,16]$. Until his landmark publication in 1916, Elsberg had performed a total of nine intramedullary operations, of which seven were rated as successful and two unsuccessful [13].

In other publications of that time, the authors had not operated on the patients themselves. The surgeon was only named, and operative aspects were treated only marginally $[11,47]$. Compared to other surgically qualified authors $[12$, $16,26,29,57,58]$, a superior wealth of surgical details, conceptual considerations and recommendations can be found in the communications of Veraguth and Brun, which are otherwise only found in the communications of Krause [27] and thereafter of Elsberg [13]. Their reports convey a passion for the subtlety of medical practice that was unique for the time, especially in the complex field of intramedullary spinal cord surgery.

According to our research, Hans Brun should be remembered as the third surgeon (after von Eiselsberg and Elsberg) who successfully removed an intramedullary lesion in a patient. Tribute for the first two such surgeries should be paid to von Eiselsberg (successful surgery on 13 November 1907, a thoracic "neurofibrosarcoma") and Elsberg with the successful operation on 13 and 20 January 1910 (cervical glioma). Brun followed as the third on 15 February 1910 (cervical tuberculoma [55]) and Krause as the fourth on 5 November 1911 with the resection of an intramedullary glioma in his patient (without improvement [27]). Griessenauer gives the first two positions to von Eiselsberg and Krause [20]. Krause, however, had reported on the resection of a thoracic intramedullary tuberculoma, but the exact operation date is not known. The patient died 16 days after surgery [27]. Cushing had performed no more than an extended biopsy on his patients with an intramedullary tumor [12].

Among those who then consistently continued the surgical efforts in this area, Elsberg and Adson should be noted. These and others would report on considerably more patients and have higher success rates in the surgical therapy of patients with intramedullary tumors in the years to come [13, 14, 20, 59].

\section{Conclusion}

Brun should be remembered as an early and successful surgeon in this special field. His operating performances are demonstrated in this article in detail. His achievements in the fields of brain and disc herniation surgery are also described.

Conflicts of interest None.

\section{References}

1. Abbé R (1890) Spinal surgery—a report of eight cases. Med Rec 38: $87-92$

2. Brun H (1917) Demonstration. Aus der neurologischen Abteilung der A.S.A. in Luzern. Schweiz Arch Neurol Psych 2:161-167

3. Brun H (1913) Demonstrationen und Bemerkungen zu hirnchirurgischen Fällen. Korrespondenzblatt Schweiz Aerzte 43:307-308

4. Brun H (1903) Der Schädelverletzte und seine Schicksale. Beitr klin Chir 38:H1 (192-297), H192 (289-407), H193 (601-691)

5. Brun H (1932) Prophylaxe und Behandlung der Liquorfisteln. Beitr klin Chir 156:541-550

6. Brun H (1911) Über einen zweiten Fall von operativer Entfernung eines subpial gelegenen Rückenmarkstumor. Dtsch Z Chir 110: 487-506

7. Brun H (1914) Weitere hirnchirurgische Erfahrungen. Korrespondenzblatt Schweiz Aerzte 44:1041-1044

8. Brun H (1926) Zur Technik der osteoplastischen Resektion des Schädels, Knochen- und Duraplastik bei der Behandlung von Hirntumoren. Septième Congrès De La Societé Internationale de Chirurgie, vol 1 Rome, 7-10 avril

9. Bruns L (1895) Klinische und pathologisch-anatomische Beiträge zur Chirurgie der Rückenmarkstumoren. Arch Psychiatr Nervenkrankheiten 28:97-168

10. Bynum WF, Bynum H (2007) Dictionary of Medical Biography. Greenwood Press, Westport

11. Church A, Eisendrath DW (1892) A contribution to spinal cord surgery. Am J Med Sci 103:395-412 
12. Cushing $H$ (1910) The special field of neurological surgery: five years later. Bull Johns Hopkins Hosp 21:325-339

13. Elsberg CA (1916) Diagnosis and Treatment of Surgical Diseases of the Spinal Cord and its Treatments. WB Saunders, Philadelphia

14. Elsberg CH (1920) Concerning spinal cord tumors and their surgical treatment. Am J Med 159:194-207

15. Elsberg $\mathrm{CH}$ (1912) Observations upon a series of forty-three laminectomies. Ann Surg 55:217-226

16. Elsberg CH, Beer E (1911) The operability of intramedullary tumors oft he spinal cord. Am J Sci 142:630-647

17. Förster O (1917) Fall von intramedullärem Tumor, erfolgreich operiert. Berl Klin Wochenschr 54:388

18. Gowers WR, Horsley V (1888) A case of tumour of the spinal cord. Removal, recovery. Med Chir Trans 53:377-428

19. Greenblatt SH (1997) A History of Neurosurgery. AANS Park Ridge, Illinois

20. Griessenauer CJ, Tubbs RS, Shoja MM, Raborn J, Boes CJ, Mortazavi MM, Lanzino G (2013) Alfred W. Adson (1887-1951): his contributions to surgery for tumors of the spine and spinal cord in the context of spinal tumor surgery in the late 19th and early 20th centuries. J Neurosurg Spine 19:750-758

21. Henschen SE, Lennander KG (1902) Rückenmarkstumor, mit Erfolg exstirpiert. Mitt Grenzgeb Med Chir 10:673-712

22. Hildebrandt G, Stienen MN, Patzer J, Surbeck W (2012) Neurosurgical contributions of the Swiss surgeon, Rudolf Ulrich Krönlein-a further pioneer in Swiss neurosurgery. Acta Neurochir (Wien) 154:1923-1933

23. Hildebrandt G, Surbeck W, Stienen MN (2012) Emil Theodor Kocher: the first Swiss neurosurgeon. Acta Neurochir (Wien) 154: $1105-1115$

24. Hofmann C (1910) Eine einfache Art der temporären Laminektomie. Zentralbl Chir 37:706-707

25. Klieneberger OL (1910) Ein eigentümlicher Liquorbefund bei Rückenmarkstumor. Monatsschr Psychiatr Neurol 28:346-354

26. Krause F (1906) 78. Versammlung Deutscher Naturforscher und Aerzte. Dtsch Med Wochenschr 32:2011-2013

27. Krause F (1911) Chirurgie des Gehirns und des Rückenmarks. Urban und Schwarzenberg Berlin, Wien

28. Krause F (1909) Erfahrungen bei 26 Rückenmarksoperationen mit Projektionen. Dtsch Z Nervenheilkunde 36:106-113

29. Krause F (1901) Zur Segmentdiagnose der Rückenmarksgeschwülste, nebst einem neuen durch Operation geheilten Fall. Berl Klin Wochenschr 38:541-610

30. Krauss WC (1910) Three cases of spinal cord tumors observed within a period of ten days; observations on the behavior of the cerebrospinal fluid. J Nerv Ment Dis 4:222-236

31. Küttner H (1908) Beiträge zur Chirurgie des Gehirns und Rückenmarks. Berl klin Wochenschr 45:706-710

32. Leyden Ev (1874) Klinik der Rückenmarks-Krankheiten. Verlag von August Hirschwald, Berlin

33. Macewen W (1888) An address on the surgery of the brain and the spinal cord delivered at the Annual Meeting of the British Medical Association, held in Glasgow, August 9th, 1888. Br Med J 2:302-309

34. Nonne M (1910) Ueber das Vorkommen von starker Phase 1-Reaktion bei fehlender Lymphocytose bei 6 Fällen von Rückenmarkstumor. Dtsch Z Nervenheilkunde 40:161-167

35. Nonne M (1913) Weitere Erfahrungen zum Kapitel der Diagnose von komprimierenden Rückenmarkstumoren. Dtsch Z Nervenheilkunde 47-48:437-503

36. Oppenheim H (1909) Diagnose und Behandlung der Geschwülste innerhalb des Wirbelkanals. Dtsch Med Wochenschr 44:19051911
37. Oppenheim H (1902) Ueber einen operativ behandelten Fall von Rückenmarkstumor. Berl Klin Wochenschr 39:905-908

38. Oppenheim H, Borchardt M (1913) Beitrag zur chirurgischen Therapie des ,,intramedullären Rückenmarkstumors“. Mitt Grenzgeb Med Chir 26:811

39. Paltauf R (1910) Protokoll der administrativen Sitzung der k.k. Gesellschaft der Aerzte in Wien am 4.3.1910. Wien Klin Wochenschr 23:375

40. Putnam JJ, Warren JC (1899) The surgical treatment of tumors within the spinal canal. Am J Med Sci 118:377-393

41. Reichmann V (1912) Ueber einen operativ geheilten Fall von mehrfachen Rückenmarksgeschwülsten bei Recklinghausenscher Krankheit nebst Bemerkungen über das chemische und cytologische Verhalten des Liquor cerebrospinalis bei Gehirn- und Rückenmarksgeschwülsten. Dtsch Z Nervenheilkunde 44:95-110

42. Röpke W (1911) Ueber die operative Entfernung intramedullärere Rückenmarkstumoren, zugleich ein Beitrag zur Kenntniss über die Beschaffenheit des Lumbalpunktats bei Rückenmarkstumoren. Arch klin Chir 96:963-980

43. Röpke W (1910) Zur Technik der Laminektomie in der Behandlung von Rückenmarkstumoren. Zentralbl Chir 13:1076

44. Rothmann M (1913) Gegenwart und Zukunft der Rückenmarkschirurgie. Berl Klin Wochenschr 50:528-533

45. Schlesinger H (1898) Beiträge zur Klinik der Rückenmarks- und Wirbeltumoren. Fischer Jena

46. Schultze F (1899) Ueber Diagnose und erfolgreiche Behandlung von Geschwülsten der Rückenmarkshäute. Dtsch Z Nervenheilkunde 16: 114-139

47. Schultze F (1912) Weiterer Beitrag zur Diagnose und operativen Behandlung von Geschwülsten der Rückenmarkshäute und des Rückenmarks. Dtsch Med Wochenschr 38:1676-1679

48. Schultze F (1913) Zur Diagnostik und operativen Behandlung der Rückenmarkshautgeschwülste. Mitt Grenzgeb Med Chir 12:153-212

49. Stegmann M (1992) Hans Brun und die Knochenchirurgie. Dissertation. Universität Zürich

50. Stienen MN, Surbeck W, Tröhler U, Hildebrandt G (2013) Littleknown Swiss contributions to the description, diagnosis, and surgery of lumbar disc disease before the Mixter and Barr era. J Neurosurg Spine 19:767-773

51. Süssli P (1991) Otto Veraguth 1870-1944. Juris Zürich

52. Trutmann HW (1946) Nachruf zum Gedenken an Professor Brun. Luzerner Tagblatt 25(6):1946

53. Veraguth O (1944) Eine neurochirurgische Reminiszens. Festschrift zu Ehren von Prof. Dr. Hans Brun anlässlich seines 70. Geburtstages17. Juni 1944. Schwabe Verlag Basel, pp 648-649

54. Veraguth O (1929) Neurologische Skizzen. Schweiz Med Wochenschr 59:154-158

55. Veraguth O, Brun H (1910) Subpialer, makroskopisch intramedullärer Solitärtuberkel in der Höhe des vierten und fünften CervicalsegmentesOperation-Genesung. Korrespondenzblatt Schweiz Aerzte 40:10971109

56. Veraguth O, Brun H (1916) Weiterer Beitrag zur Klinik und Chirurgie des intramedullären Konglomerattuberkels. Korrespondenzblatt Schweiz Aerzte 56:385-408

57. von Eiselsberg A, Marburg O (1917) Zur Frage der Operabilität intramedullärer Rückenmarkstumoren. Arch Psychiatr Nervenkr 59:453-461

58. von Eiselsberg A, Ranzi E (1913) Ueber die chirurgische Behandlung der Hirn- und Rückenmarkstumoren. Arch klin Chir 102:309-468

59. Woltman HW, Kernohan JW, Adson AW, Craig WM (1951) Intramedullary tumors of spinal cord and gliomas of intradural portion of filum terminale; fate of patients who have these tumors. AMA Arch Neurol Psychiatry 65:378-395 